\title{
Solanum tuberosum peel waste: an attractive substrate for Aspergillus sp. CP to produce glucohydrolase under solid state fermentation
}

\author{
Erum Hanif ", Rattab Abbas, Shafaq Aiyaz Hassan, Raheela Rahmat Zohra \\ University of Karachi, Department of Biotechnology, Faculty of Science and Engineering, 75270, Karachi, Pakistan. \\ Correspondence Author: Erum Hanif, University of Karachi, Department of Biotechnology, Faculty of Science and Engineering, 75270, Karachi, Pakistan.
} *email of the corresponding author: erumh@uok.edu.pk

Received date: 18 February 2019, Accepted date: 5 May 2019, Online date: 26 May 2019

Copyright: (C) 2019 Erum Hanif, et al., This is an open-access article distributed under the terms of the Creative Commons Attribution License, which permits unrestricted use, distribution, and reproduction in any medium, provided the original author and source are credited.

\begin{abstract}
Filamentous fungi are being selected for the production of industrial enzymes as they have enormous capacity of production, on low cost solid substrates. Glucohdrolase is one of the industrial enzymes produced by Aspergillus niger. It hydrolyzed alpha 1, 4 and beta 1,6 glycosidic linkage, yield glucose by hydrolyzing polysaccharides from non-reducing end. Major utilization of glucohydrolase is in starch and beverage industry for the preparation of high fructose corn syrup.

The present study is focused to utilize low cost, easily available potato peel waste as substrate for the production of glucohydrolase. Solid state fermentation optimization was carried out by providing suitable physiochemical parameters results in highest enzyme production i.e. 12333 units $/ \mathrm{ml} / \mathrm{min}$. Dry potato peels 20 grams per fermentation flask, particle size $2 \mathrm{~mm}$, was moisten with a fermentation medium containing soluble potato starch $10 \mathrm{~g} / \mathrm{L}$, peptone1g/L, yeast extracts $2 \mathrm{~g} / \mathrm{L}$ and $\mathrm{MgSO}_{4.7 \mathrm{H}_{2} \mathrm{O}} 0.5 \mathrm{~g} / \mathrm{L},(\mathrm{pH}$ ) with $50 \%$ of final moisture content. Fermentation was started with the inoculum of $7.5 \times 10^{4}$ spores per flask and fermentation was carried out at $20^{\circ} \mathrm{C}$ for 5 days.
\end{abstract}

Keywords: Glucoamylase, SSF, Potato peel, Aspergillus

\section{INTRODUCTION}

The potato plant is scientifically known as Solanum tuberosum; it is a short herbaceous plant with underground stem called tuber, contains a lot of starch. It is the fourth major crop utilized by human all around the world (Stearns et al., 1994; Mattila and Hellstrom, 2007). Processed potato products demand is continuously increasing and also result in a significant amount of processing waste (FAO, 2008; Schieber and Aranda, 2009). Potato peels consist of the major portion of waste and contain a considerable content of carbohydrate, protein, vitamin C, ferritin, riboflavin, alkaloids (Mäder et al., 2009). Potato peel waste is being used for the production of value-added products like enzymes, bio-surfactants, antioxidants ethanol, and certain polysaccharides (Liang and McDonald, 2014; Amado, 2014).

Glucoamylase (EC 3.2.1.3) is exo-enzyme of extraordinary significance for saccharification of starchy materials and other related oligosaccharides. Glucoamylase successively hydrolyzes 1,4-alpha glycosidic bond from the non-reducing end of starch and other related polysaccharides and release free glucose, which then used as a feedstock for the process of fermentation (Gupta et al., 2003; Norouzian et al., 2006). Industrial production of glucoamylase has been performed by the fungi, Aspergillus niger (Wang et al., 2006). Glucoamylase has different applications in significant areas of food processing, animals feed, fermentation biotechnology, paper making, fabric texture, grain hydrolysis for the alcohol industry (Zambare, 2011).

The production of glucoamylase from different Aspergillus species including Aspergillus niger, Aspergillus fumigatus, Aspergillus oryzae, Aspergillus terreus and Aspergillus awamori (Negi and Banerjee 2009; Varalakshmi 2009; Biesebeke et al., 2005; da Silva and Peralta 1998; Ghose et al., 1990) have been reported previously. Aspergillus and Rhizopus are extensively utilized for the industrial production of glucoamylase (Zambare, 2011). Both of above-stated molds were considered an ultimate 
Citation: Erum Hanif, et al., Solanum tuberosum peel waste: an attractive substrate for Aspergillus sp. CP to produce glucohydrolase under solid state fermentation. Australian Journal of Basic and Applied Sciences, 13(5): 97-105. DOI: 10.22587/ajbas.2019.13.5.10

applicant for industrial production because of their rich nature, non-fastidious requirements, plentiful amount of production prospective, 100\% glucose yield, extracellular secretion, have low transglycosylation action (Mertens and Skory, 2007).

SSF offer increases productivity on easier and more affordable raw materials, after the optimization of physiochemical factors (Yazaid et al., 2017). Potato peel waste as a solid substrate also performs the role of the physical structure that supports the growth of microorganisms in addition to the rich nutrients supply (Gebrechristos and Chen, 2018). Glucohydrolase production in SSF has been reported by Morita and Fujio, 2000; Wang et al., 2006; Sun and Zhang, 2007; Zambare, 2011, and Onofre et al., 2011).

\section{MATERIAL AND METHODS}

\section{Screening and Identification of Glucohydrolase Producer}

Initial isolation and identification of Aspergillus were done by colony morphology and microscopic characteristics. Pure cultures were maintained on Potato Dextrose Agar (PDA) at $4{ }^{\circ} \mathrm{C}$ and were repeatedly subculture after 30 days. Isolated strains were screened for amylase production on starch agar medium; $\mathrm{g} \mathrm{L}^{-1}$ : (Peptone 5.0; Yeast extract 1.5; Sodium chloride 5.0; Starch 10.0; and Agar Agar 20.0). Hydrolytic zones were visualized using Lugol's iodine solution. Positive cultures was further incubated in fermentation medium containing; $\mathrm{g} \mathrm{L}^{-1}$; (Potato starch 10.0; Yeast extract 2.0; Peptone 1.0; and $\mathrm{MgSO}_{4}$ 0.5, $\mathrm{pH}^{5.0}$ ). After incubation at $30^{\circ} \mathrm{C}$ for 04 days, culture broth filtered through Whatman filter paper No. 1 and collected cell-free filtrate was used for the estimation of glucohydrolase produced.

\section{Selection of Fermentation Mode}

To produce high titer of glucohydrolase, the mode of fermentation was selected by comparing submerged fermentation with solid state fermentation. Submerged fermentation was carried out as described above and Solid state fermentation was started with 10 grams of potato peels as a substrate in individual Erlenmeyer flask $(250 \mathrm{ml})$ and moistens with $10 \mathrm{ml}$ of fermentation medium. The control flask containing potato peel was moistened with the same volume of distilling water. The flasks were then autoclaved, and after that, each flask was inoculated with $1.0 \mathrm{ml}$ of spore suspension. Fermentation was carried out for five days under the static condition at $35 \pm 2^{\circ} \mathrm{C}$.

\section{Recovery of Glucohydrolase}

After fermentation, glucohydrolase was recovered by re-suspending the solid substrate after the addition of $25 \mathrm{mM}$ sodium acetate buffer, $\mathrm{pH} 4(50 \mathrm{ml})$ of and vortex for half an hour on a magnetic stirrer. The extracted solution was filtered through filter paper (Whatman No.1) to obtain cell-free filtrate. Glucohydrolase activity was estimated in the cell-free filtrate.

\section{Determination of Glucohydrolase activity}

Glucohydrolase activity was determined in $1 \mathrm{ml}$ of $1 \%$ potato starch solution in $25 \mathrm{mM}$ sodium acetate buffer $\mathrm{pH} 4.0 \mathrm{with} 0.1 \mathrm{ml}$ of enzyme solution. The reaction was carried out for 5 minutes at $50^{\circ} \mathrm{C}$, and then after $5 \mathrm{~min}$, the reaction was stopped by boiling for 5minutes. The amount of glucose formed was determined by Glucose oxidase (GOD/POD) method using a commercially available glucose kit. One unit of enzyme is defined as the enzyme used to produce one micromole of glucose formed per minute per $\mathrm{ml}$ in standard assay condition (Trinder, 1969).

\section{SSF Substrate Preparation}

Potato peels were used as a substrate. They were obtained from the local market. For potato peel, the substrate was washed thoroughly with tap water, air dried and finally, oven dried at $70^{\circ} \mathrm{C}$ for three days, ground with the help of mortar and pestle, $2 \mathrm{~mm}$ of particle size were obtained by sieving with the help of sieve having mesh size 10, stored in poly-ethylene bags at room temperature.

\section{Inoculum Preparation}

Inoculum preparation was done by suspending the spores in $15 \mathrm{ml}$ of sterile Tween $80(0.8 \%)$ from 5 days-old culture Petri plate, collected in sterile test tubes (Kheng and Omar 2005). Spore count was determined by Neubauer Chamber, and each 250ml flask was inoculated with $1 \mathrm{ml}$ of spore suspension having a concentration of $7.5 \times 10^{4}$ spores $/ \mathrm{ml}$ for solid-state fermentation.

\section{Optimization of physiochemical parameters}

\section{Influence of incubation time on glucohydrolase production}

The effect of fermentation time on glucohydrolase production was examined by incubating the flasks for $1,3,5$, and seven days. Each flask containing 20 grams of substrate and $20 \mathrm{ml}$ of sterile fermentation medium were inoculated with $1 \mathrm{ml}$ of spore suspension and incubated at $35 \pm 2{ }^{\circ} \mathrm{C}$ in the incubator. The enzyme was extracted and assayed after completion of the designated time interval for fermentation.

\section{Influence of $\mathbf{p H}$ on glucohydrolase production}

The effect of fermentation $\mathrm{pH}$ on glucohydrolase production was determined by adjusting mineral medium $\mathrm{pH}$ at five different values starting from $\mathrm{pH} 3$ to $\mathrm{pH}$ 7. The flasks provided with 20 grams of substrate were moistened with $20 \mathrm{ml}$ of sterile fermentation mediums (varying $\mathrm{pH})$ were inoculated with $1 \mathrm{ml}$ of spore suspension $\left(7.5 \times 10^{4} / \mathrm{ml}\right.$ in Tween 80$)$ and incubated for five days at $35 \pm 2^{\circ} \mathrm{C}$ in the incubator. 


\section{Influence of inoculum size on glucohydrolase production}

The importance of inoculum size was studied by inoculating each flask with the following number of spores i.e.1.5 $10^{3}, 7.5 \times 10^{3}$, $1.5 \times 10^{4}, 7.5 \times 10^{4}$, and $1.5 \times 10^{5}$ in each flask. Each flask contains $20 \mathrm{~g}$ of the substrate with $20 \mathrm{ml}$ of sterile fermentation medium was inoculated with different spore concentration and were incubated at $35 \pm 2^{\circ} \mathrm{C}$ for five days.

\section{Influence of temperature on glucohydrolase production}

The impact of fermentation temperature on glucohydrolase production was examined by incubating flasks at different temperatures ranging from 20 to $40^{\circ} \mathrm{C}$. The container containing 20 grams of substrate and $20 \mathrm{ml}$ of sterile fermentation medium was inoculated with $1 \mathrm{ml}$ of spore suspension and incubated for five days at $20,25,30,35$ and $40^{\circ} \mathrm{C}$ in different incubators.

\section{Influence of particle size on glucohydrolase production}

The influence of particle size of potato peel on glucohydrolase production was investigated by comparing the different particle size, i.e., $0.5,1,2$, and $3 \mathrm{~mm}$. Flasks containing one of the mentioned particle sizes were moistened with $20 \mathrm{ml}$ of fermentation medium, inoculated with $1 \mathrm{ml}$ of spore suspension incubated at $35 \pm 2{ }^{\circ} \mathrm{C}$ for five days.

\section{Influence of substrate content on glucohydrolase production}

The impact of substrate content on enzyme production was tested by varying the amount of potato peel substrate to the mineral medium ratio (w/v). The $250 \mathrm{ml}$ Erlenmeyer flasks containing $5 \mathrm{~g}, 10 \mathrm{~g}, 20 \mathrm{~g}, 30 \mathrm{~g}$ and 35 grams of the substrate in the respective flask was moistened with the $20 \mathrm{ml}$ of fermentation medium inoculated with $1 \mathrm{ml}$ of spore suspension and incubated for five days at $35 \pm 2^{\circ} \mathrm{C}$ in the incubator.

\section{Influence of moisture level on glucohydrolase production}

The effect of moisture level on glucohydrolase production was evaluated in solid substrate by changing substrate to fermentation media ratio $(\mathrm{w} / \mathrm{v})$ in the range of $20 \%-60 \%$. The $250 \mathrm{ml}$ of Erlenmeyer flasks containing $20 \mathrm{~g}$ of dry potato peels as substrate and $4.6 \mathrm{ml}, 8.5 \mathrm{ml}, 13.5 \mathrm{ml}, 20 \mathrm{ml}$ and $30 \mathrm{ml}$ of medium maintaining $20 \%, 30 \%, 40 \%, 50 \%$ and $60 \%$ moisture levels respectively. After sterilization, flasks were inoculated with $1 \mathrm{ml}$ of spore suspension $\left(7.5 \times 10^{4} / \mathrm{ml}\right)$ and incubated for five days at $35 \pm 2^{\circ} \mathrm{C}$ in an incubator.

\section{RESULTS AND DISCUSSION}

Screening and selection of fermentation mode for glucohydrolase production

Aspergillus strains were screened for the production of glucohydrolase on starch agar medium, Aspergillus niger CP, isolated from rotten capsicum, expressed a clear starch hydrolytic zone around the colony. Quantitative estimation confirmed that Aspergillus sp. CP is a hyper producer of glucohydrolase producing 3,211.0 units/ml/min under solid state fermentation then Submerged fermentation (1689 units/ml/min) (Figure 1). Further optimization studies were carried out using Aspergillus sp. CP for the production of glucohydrolase under solid state fermentation.

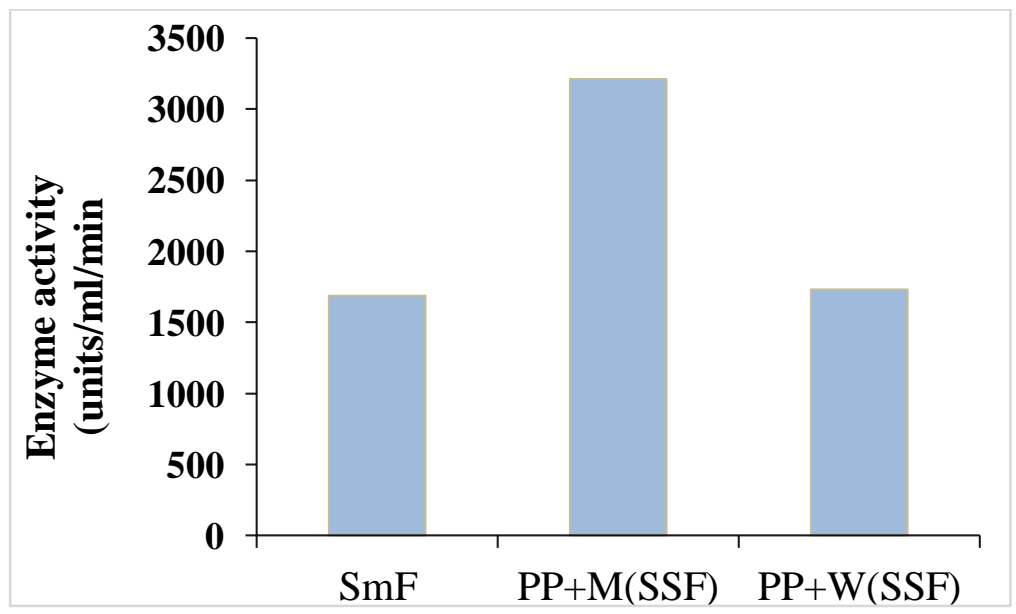

Figure1: Selection of fermentation mode for glucohydrolase production by Aspergillus $s p$. CP. SMF = submerged fermentation, $\mathrm{SSF}=$ Solid-state fermentation. $\mathrm{PP}=$ potato peel, $\mathrm{M}=$ fermentation medium, $\mathrm{W}=$ Distil water.

In the present study, potato peels waste shows considerably higher glucohydrolase production, as it is a rich source of carbohydrate and protein. Rapid microbial spoilage of potato peels waste grounds a serious disposal problem in the potato industry and could be solved by utilizing waste as a selective substrate for the production of starch degrading enzymes (Mahmood et al., 2016; Tamilarasan et al., 2010; Schieber and Saldana, 2009). Optimization of glucohydrolase production was performed under SSF using a fermentation medium containing soluble potato starch, organic nitrogen sources yeast extract and peptone, and $\mathrm{MgSO}_{4}$. The previous reports describe the positive impact on enzyme production and secretion by supplementing the solid substrate with an available form of potato starch and yeast extract (Mustaq et al., 2017; Hassan and Karim, 2015; Nwagu and Okolo 2010). 


\section{Influence of incubation period on the production of glucohydrolase}

Incubation period plays an integral role in substrate utilization and enzyme production. The effect of incubation period was studied by checking enzyme activities after 1,3,5, and seven days of incubation. In our experiment, maximum glucoamylase production $(3357 \mathrm{u} / \mathrm{min} / \mathrm{ml})$ was obtained on the $5^{\text {th }}$ day of incubation (Figure 2). Maximum enzymes production was mostly reported in 5 days, and afterward, enzyme activity declined, which may be due to an increase in acid production as waste or may be due to complete nutrient depletion. It was found that amylase production was highest on the $5^{\text {th }}$ day of the incubation period (Gupta et al. 2008; Chimata et al., 2010).

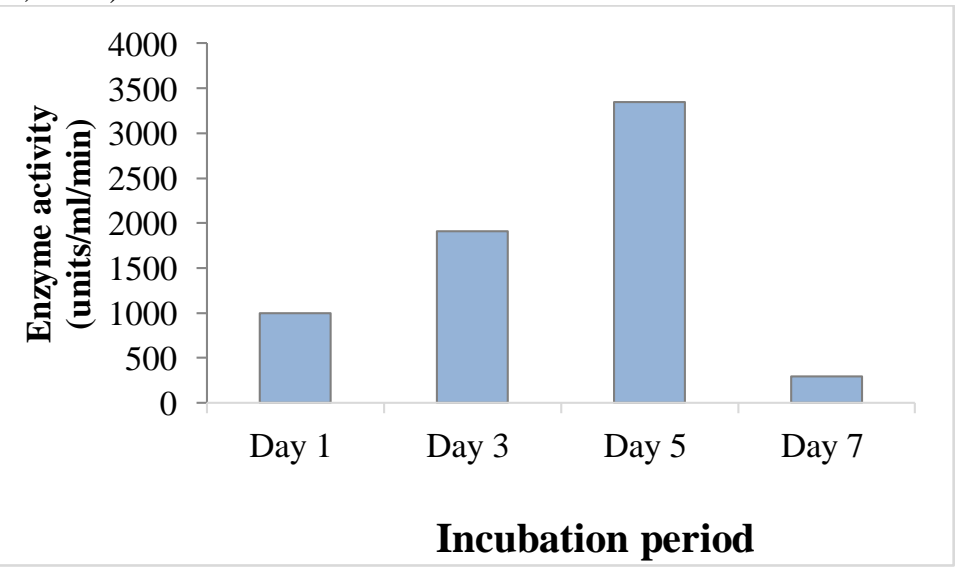

Figure 2: Influence of incubation period on Glucohydrolase production in SSF by Aspergillus sp. CP.

\section{Influence of $\mathbf{p H}$ on glucohydrolase production}

The effect of $\mathrm{pH}$ on glucoamylase activity of Aspergillus sp. CP was studied by varying the $\mathrm{pH}$ from $\mathrm{pH} 3$ to 7 . Results from the graph showed enzymes production was monitored in $\mathrm{pH}$ range from $\mathrm{pH} 4$ to 6 . At $\mathrm{pH}$ five maximum enzyme productions was recorded and gradually decreases with $\mathrm{pH}$ 6. It is indicated from the graph that $\mathrm{pH} 5$ is best for maximum enzyme production (Figure 3). Usually, it is desirable to use fungus, which will prefer $\mathrm{pH}$ values slightly acidic, to control contaminations with another organism (Kar \& Ray, 2008; Mahmood et al., 2016).

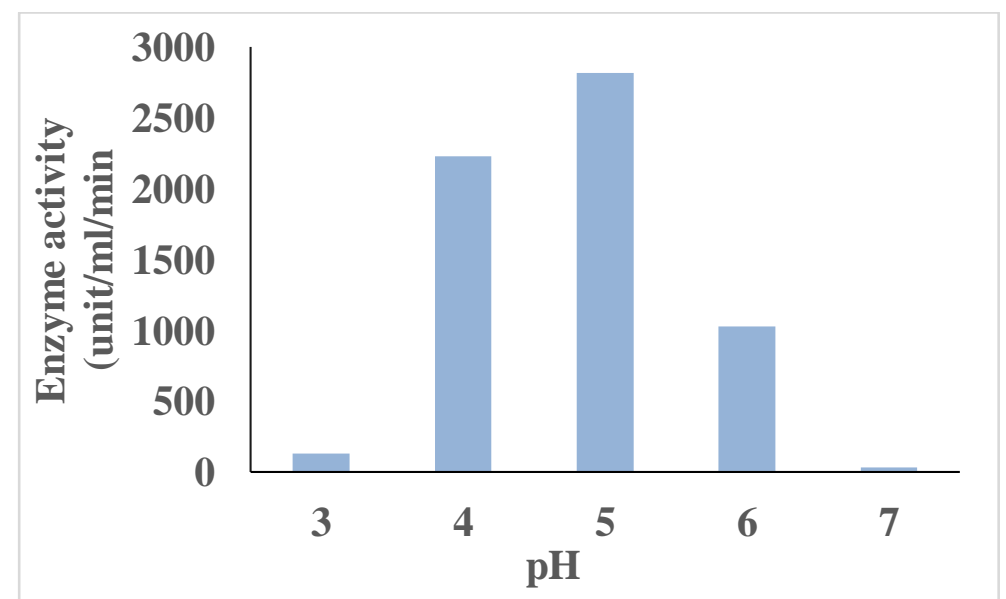

Figure 3: Influence of initial $\mathrm{pH}$ on Glucohydrolase production by Aspergillus sp. CP.

\section{Influence of inoculum size on glucohydrolase production}

Inoculum concentration is also an essential component in solid state fermentation. The presented results showed that the inoculum size of $7.5 \times 10^{4}$ spores gives optimum enzyme production in the $20 \mathrm{~g}$ of potato peel as substrate (Figure 4 ). Inoculum size of $1 \times 10^{4}$ spores of Aspergillus niger USM AI 1 was reported for xylanase production (Kheng and Omar, 2005). 


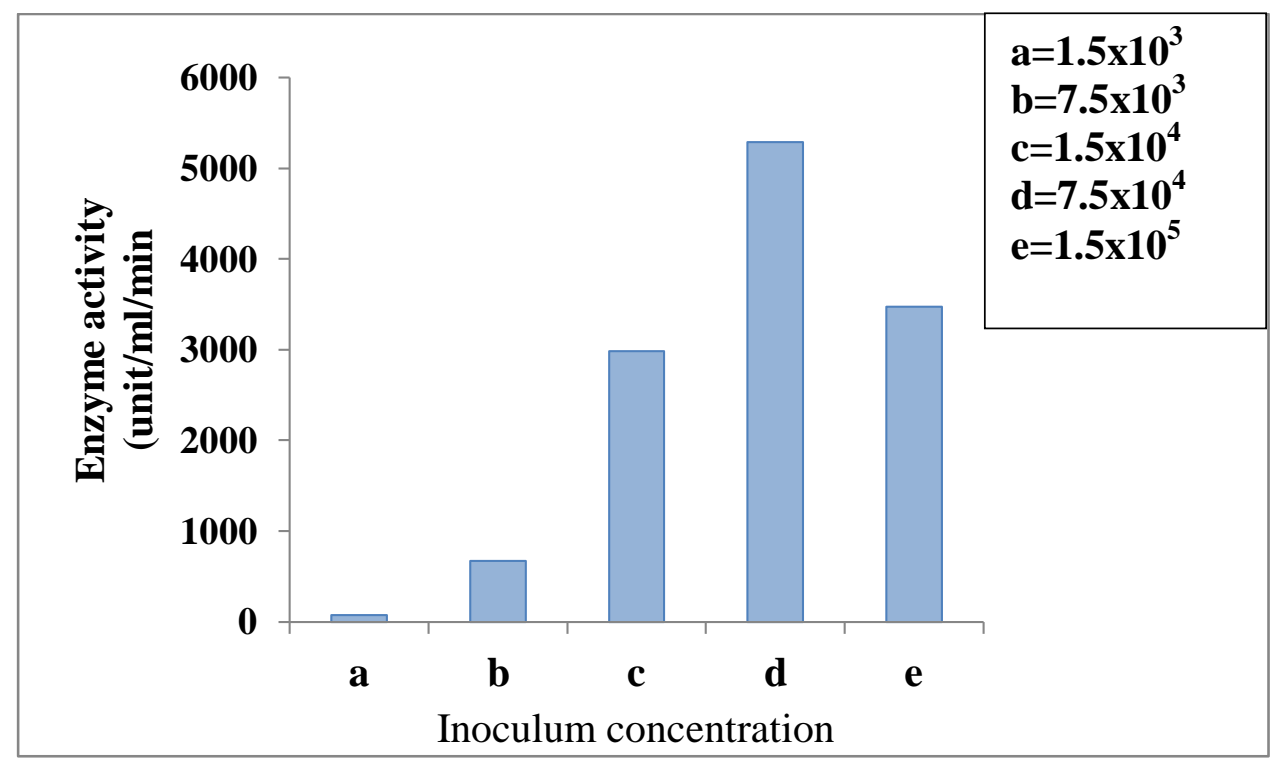

Figure 4: Influence of inoculum concentration on glucohydrolase production by Aspergillus sp. CP.

\section{Influence of incubation temperature on the production of enzymes}

Incubation temperature not only influences the growth of microorganisms but also their biological activities. The effect of temperature on glucoamylase activity was investigated by keeping temperatures under following given range, i.e. 20 to $40^{\circ} \mathrm{C}$. The results represent in the graph clearly shows that maximum enzyme activity was found at $20^{\circ} \mathrm{C}$. It might be due to the reason that at high temperature, the growth of the fungus was inhibited and hence, enzyme formation was also inhibited (Figure 5). Maximum amylolytic activity of Aspergillus oryzae on wheat bran was reported at $30^{\circ} \mathrm{C}$ in 3 days (Sivaramakrishnan et al. 2007). Chimata et al., (2010) reported the maximum extracellular amylolytic activity of Aspergillus sp.MK07was on day five at $30^{\circ} \mathrm{C}$.

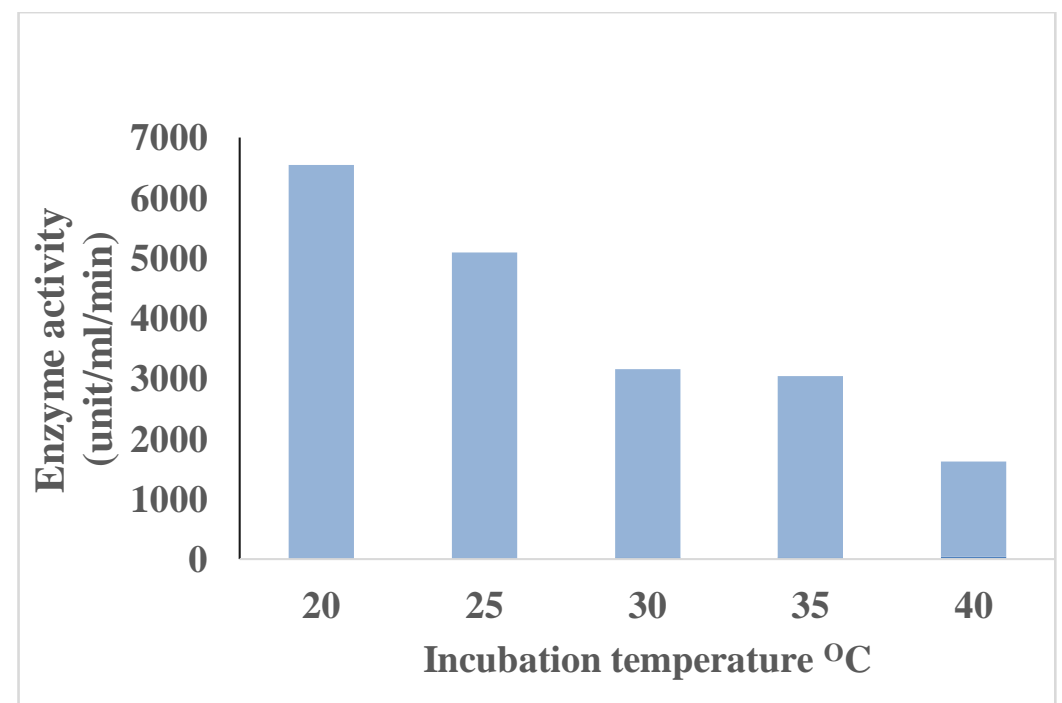

Figure 5: Influence of incubation temperature on glucohydrolase production by Aspergillus sp. CP.

\section{Influence of particle size on glucohydrolase production}

Highest enzyme activity was reported with $2 \mathrm{~mm}$ particle size, and then enzyme activity gradually decreases with increasing particle size to $3 \mathrm{~mm}-4 \mathrm{~mm}$, as less surface area available to the microbial enzyme to be acted upon (Figure 6). Appropriate particle size should provide enough surface area for mycelium growth of fungus and satisfy the oxygen demand (Pandy, 2003). 


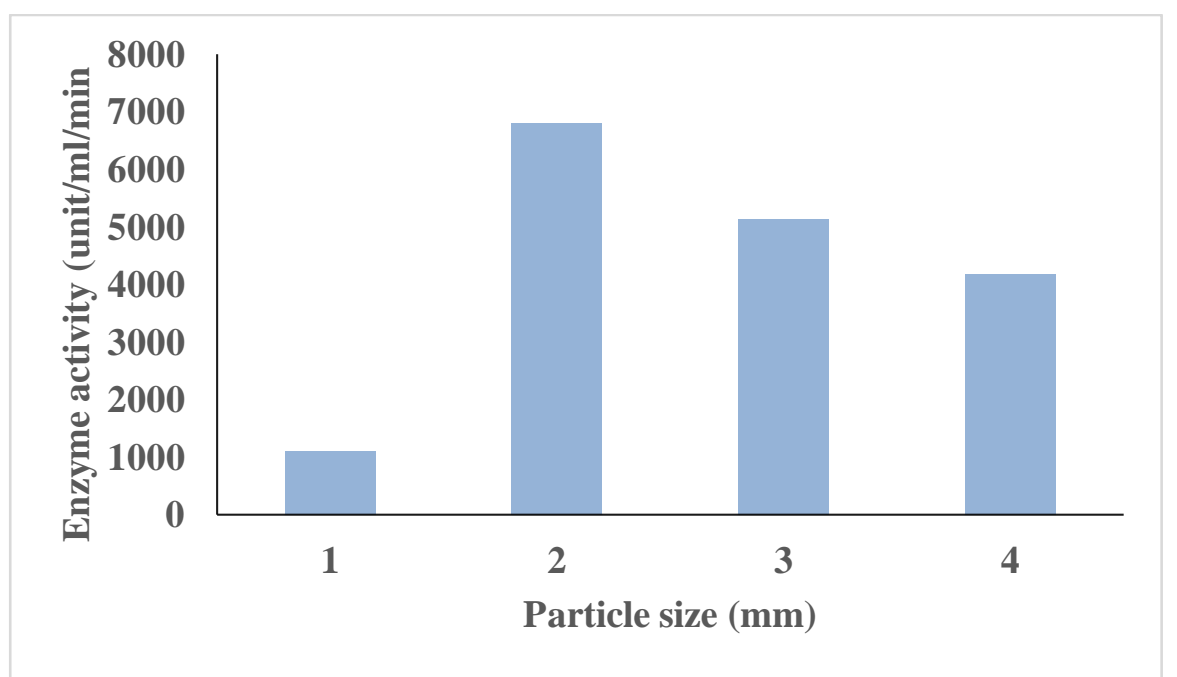

Figure 6: Influence of particle size on glucohydrolase production by Aspergillus sp. CP

\section{Influence of substrate content on glucohydrolase production}

Solid state fermentation is greatly affected by substrate content. The effect of substrate content on enzyme production was evaluated; $20 \mathrm{~g}$ of substrate per $250 \mathrm{ml}$ of Erlenmeyer flasks (1:12.5) shows the maximum activity of the enzyme (Figure 7). Results illustrate that increase or decrease in substrate mass (20g/flask) drastically decrease enzyme yield, as porosity and aeration were influenced (Bhatti et al., 2007).

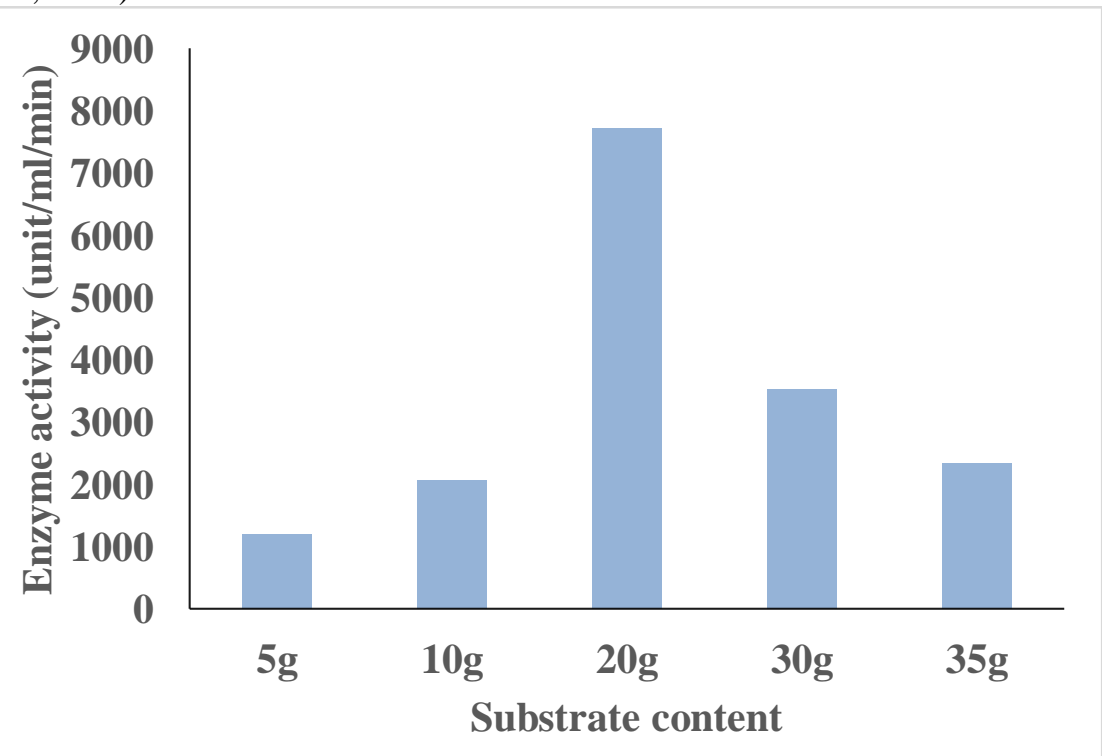

Figure 7: Influence of substrate content on glucohydrolase production by Aspergillus $s p$. CP

\section{Influence of moisture level on glucohydrolase production}

The results shown that glucohydrolase activity increases with increase in moisture content from $40 \%$ to $50 \%$, was observed maximum at $50 \%$ and then gradually fall off at $60 \%$ moisture content as the substrate became waterlogged and decrease surface to volume ratio (Figure 8). Morita and Fujio, (2000) reported that $45 \%$ initial moisture level was optimum for enzyme production by Rhizopus sp. MKU 40. 


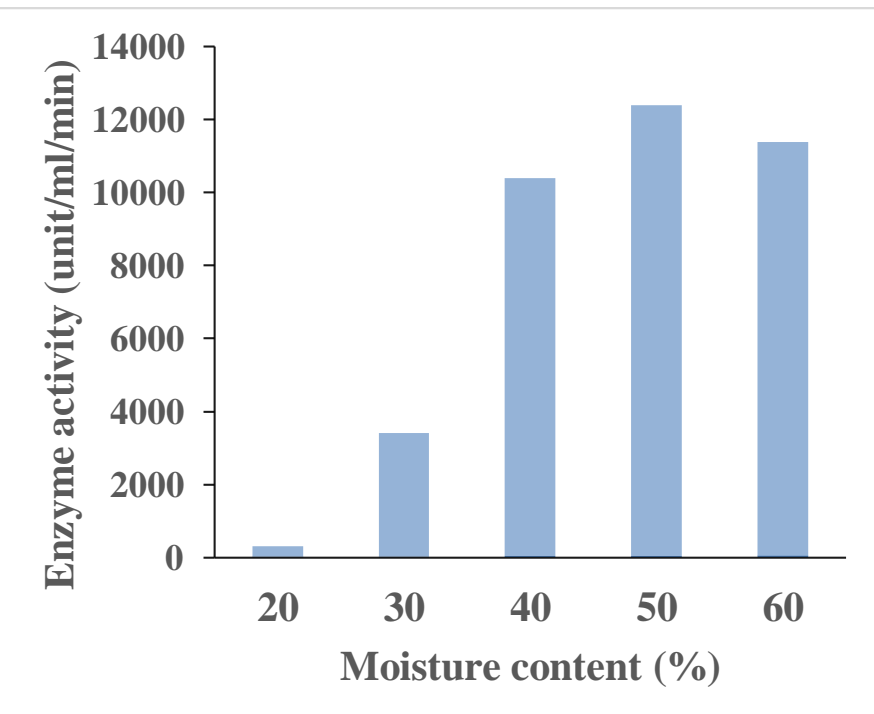

Figure 8: Influence of moisture content on glucohydrolase production by Aspergillus $s p$. CP

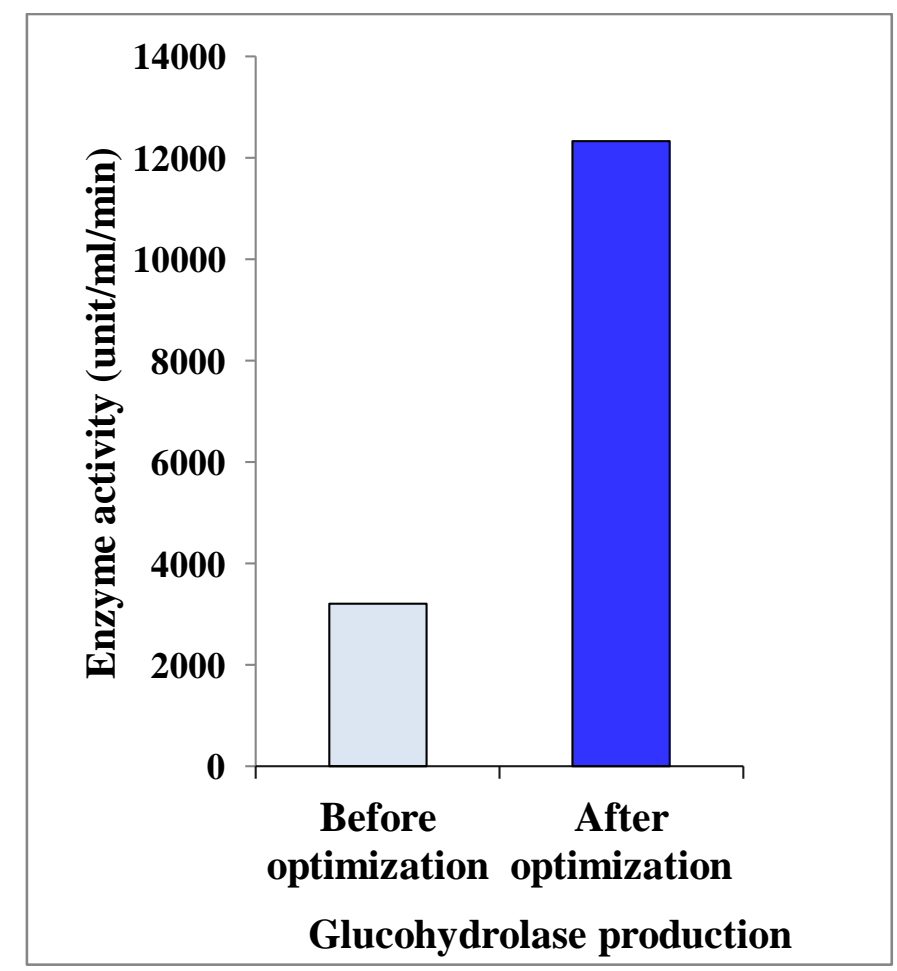

Figure 9: Glucohydrolase production before and after optimization of SSF on potato peel waste by Aspergillus sp. CP.

This study, which was aimed to investigate the optimum conditions under solid state fermentation for maximum production of glucoamylase by Aspergillus strain CP. Highest enzyme activities, i.e., 12333 units $/ \mathrm{ml} / \mathrm{min}$, were found when 20 grams of potato peel was used as a substrate with $50 \%$ of moisture content heaving a particle size $2 \mathrm{~mm} .7 .4 \times 10^{4}$ spores were optimum inoculum size. Fermentation was carried out at $20^{\circ} \mathrm{C}$ at $\mathrm{pH} 5$ for five days (Figure 9). Hence, after optimizing all parameters, a threefold increase in glucohydrolase production was observed. Hence, it can be concluded that the utilization of potato peel waste by Aspergillus sp CP is an inexpensive, eco-friendly way of enzyme production through solid-state fermentation.

\section{CONCLUSION}

Based on the above results, filamentous fungus Aspergillus sp. CP demonstrates an extraordinary capacity for glucohydrolase production from potato peel waste based on solid-state fermentation. Optimization of process parameters in this study found to be productive and has the potential to be exploited for the production of these biotechnological importance enzymes.

\section{ACKNOWLEDGMENT}

The authors are grateful to the Department of Biotechnology, University of Karachi, Pakistan for carrying out this work. 
Citation: Erum Hanif, et al., Solanum tuberosum peel waste: an attractive substrate for Aspergillus sp. CP to produce glucohydrolase under solid state fermentation. Australian Journal of Basic and Applied Sciences, 13(5): 97-105. DOI: 10.22587/ajbas.2019.13.5.10

\section{CONFLICT OF INTEREST}

All authors declare no conflict of interest, financial or other, exists. Authors declare that they respect the journal's ethics requirements.

\section{REFERENCES}

Amado, I.R., D. Franco, M.Sánchez, C. Zapata, and J.A.Vázquez, 2014. Optimization of antioxidant extraction from Solanum tuberosum potato peel waste by surface response methodoogy. Food Chemistry, 165: 290-299. https://doi.org/10.1016/ j.foodchem.2014.05.103

Bhatti, H.N., M.H. Rashid, R. Nawaz, M. Asgher, R. Perveen, A. Jabbar, 2007. Optimization of Media for Enhanced Glucoamylase Production in Solid-State Fermentation by Fusarium solani. Food Technology and Biotechnology, 45(1):51-56.

Biesebeke, R., E. Record, N. van Biezen, M. Heerikhuisen, A. Franken, P. J. Punt, C. A. van den Hondel, 2005. Branching mutants of Aspergillus oryzae with improved amylase and protease production on solid substrates. Applied Microbiology Biotechnology, 69: 44-50.

Chimata. M.K, P. Sasidhar., S. Challa, 2010. Production of extracellular amylase from agricultural residues by a newly isolated Aspergillus species in solid state fermentation. African Journal of Biotechnology, 9(32): 5162-5169.

Da Silva, W. B., and R. M. Peralta, 1998. Purification and characterization of a thermostable glucoamylase from Aspergillus fumigatus. Canadian journal of microbiology, 44(5): 493-497.

FAO 2008. The global potato economy, International Year of Potato, 2008. Rome, Italy: FAO

Gebrechristos, H.Y., W. Chen, 2018. Utilization of potato peel as eco-friendly products: A review. Food Science Nutrition.00:1-5. https://doi.org/10.1002/fsn3.69

Ghosh, A., B. Chatterjee, and A. Das, 1990. Induction and catabolite repression of high affinity glucoamylase in Aspergillus terreus strain 4. Microbiology, 136(7): 1307-1311.

Gupta A, V. K. Gupta, D. R. Modi, L. P. Yadava, 2008. Production and characterization of alpha amylase from Aspergillus niger. Biotechnology, 7(3): 551-556.

Gupta, R., P. Gigras, H. Mohapatra, V. K.Goswami, and B.Chauhan, 2003. Microbial a amylases: a biotechnological perspective. Process Biochemistry, 38:1599-1616.

Hassan, H. and K. A. Karim, 2015. Optimization of alpha amylase production from rice straw using solid-state fermentation of Bacillus subtilis. International Journal of Science, Environment and Technology, 4:1-16.

Kar, S. and R. C. Ray, 2008. Statistical optimization of $\alpha$-amylase production by Streptomyces erumpens MTCC 7317 cells in calcium alginate beads using response surface methodology. Polish Journal of Microbiology, 57: 49-57.

Kheng P P, Omar C I (2005). Xylanase production by local fungal isolate Aspergillus niger USM AI 1 via solid state fermentation using palm kernel cake as substrate. Journal of Science and Technoogy. 27 (2): 325-336.

Liang S., A.G. McDonald, 2014.Chemical and thermal characterization of potato peel waste and its fermentation residues and potential resources for biofuel and bioproducts production. Journal of Agriculture Food Chemistry, 62: 8421-8429.

Mäder, J., H. Rawel., and L.W. Kroh, 2009. Composition of phenolic compounds and glycoalkaloids $\alpha$-solanine and $\alpha$ chaconine during commercial potato processing. Journal of Agricultural and Food Chemistry, 57: 6292-6297.

Mahmood, S., M.G. Shahid, M. Nadeem,. Irfan, and Q. Syed, 2016.Production and optimization of $\alpha$-amylase from Aspergillus niger using potato peel as substrate. Pakistan Journal of Biotechnology, 13:105-113.

Mattila, P., and J. Hellstrom, 2007. Phenolic acids in potatoes, vegetables and some of their products. Journal of Food Composition Analysis., 20:152-160.

Mertens, J. A., and C. D. Skory, 2007. Isolation and characterization of two genes that encode active glucoamylase without a starch binding domain from Rhizopus oryzae. Current microbiology, 54(6): 462-466.

Morita, H., Y. Fujio., 2000. Effect of organic nitrogen sources on raw starch-digesting glucoamylase production of Rhizopus sp. $M K U$ 40. Starch, 52:18-21.

Mushtaq, Q., M. Irfan., F. Tabssum., J. Iqbal Qazi, 2017.Potato peels: A potential food waste for amylase production. Journal of Food Process Engineering. 40:e12512. https://doi.org/10.1111/jfpe.12512

Negi, S., R. Banerjee, 2009. Optimization of extraction and purification of glucoamylase produced by Aspergillus awamori in solid-state fermentation. Biotechnology Bioprocess Engineering, 14(1): 60-66.

Norouzian, D., A. Akbarzadeh, J.M. Scharer, and M.M. Young, 2006. Fungal glucoamylases. Biotechnology advances, 24(1): $80-85$.

Nwagu .T. N. and B. N. Okolo, 2010. Growth profile and amylase hydrolytic activity of a thermophilic fungi Aspergillus fumigatus isolated from soil. Asian Journal of Biotechnology, 3(1):46-57.

Onofre, S.B., P. Steilmann, J. Bertolini, D. Rotta, A.S. Francini, Y. Kagimura, S.A. Groff, L. Mazzali, 2011. Amylolytic enzymes produced by the fungus Colletotrichum gloeosporioides in rice semi-solid fermentation. Journal of Yeast and Fungal Research, 2(3): $28-32$.

Pandey A. 2003. Solid-state fermentation. Biochemical Engineering Journal, 13(2): 81-84.

Schieber, A., and M. A .Saldana, 2009. Potato peels: a source of nutritionally and pharmacologically interesting compounds-A review. Food, 3:23-29.

Schieber, A., and M. D. Aranda, 2009. Potato peels : A source of nutritionally and pharmacologically interesting compounds - A review. Global Science Books, Food, 3(Special Issue 2):23-29.Canada. 
Sivaramakrishnan. S, D. Gangadharan, K. M. Nampoothiri, C. R. Soccol, A. Pandey, 2007. Alpha amylase production by Aspergillus oryzae employing solid-state fermentation. Journal of Science and Industrial Research. 66:621-626.

Stearns, L. D., T. A. Petry, and M. A. Krause, 1994. Potential food and non food utilization of potatoes and related by products in North Dakota. Agricultural Economics., R 322(1): 2-6.

Sun, H., X. Ge, W. Zhang, 2007. Production of a novel raw-starch digesting glucoamylase by Penicillium sp. X-1 under solid state fermentation and its use in direct hydrolysis of raw starch. World Journal of Microbiology Biotechnology, 23: 603613.

Tamilarasan, K., R. Ashok, S. Abinandan, and M. D. Kumar, 2010. Optimization of operating variables for corn flour starch hydrolysis using immobilized a-amylase by response surface methodology. International Journal of Biochemistry and Biotechnology, 6: 841-850.

Trinder, P. 1969. Determination of blood glucose using an oxidase-peroxidase system with a non-carcinogenic chromogen. Journal of clinical pathology 22.2: 158-161.

Varalakshmi, K. N., B. S. Kumudini., B. N. Nandini., J. Solomon., R. Suhas., B. Mahesh., 2009. Production and characterization of $\alpha$-amylase from Aspergillus niger JGI 24 isolated in Bangalore. Polish Journal of Microbiology, 58: $29-36$.

Wang, X.J., J.G. Bai, Y.X. Liang., 2006. Optimization of multienzyme production by two mixed strains in solid-state fermentation. Applied Microbiology Biotechnology, 73: 533-540.

Yazid, A., N., R. Barrena, D. Komilis, and A. Sánchez, 2017. Solid-state fermentation as a novel paradigm for organic waste valorization: a review. Sustainability, 9(2): 224

Zambare, V. P., 2011. Optimization of amylase production from Bacillus sp. using statistics based experimental design. Emirates Journal of Food and Agriculture, 23, 37-47. 